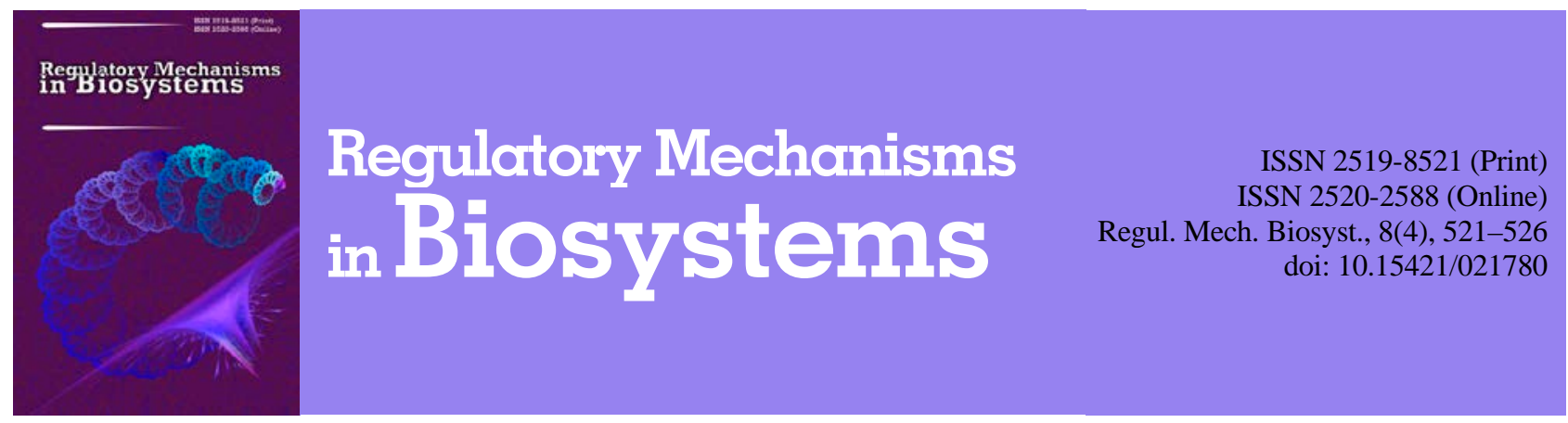

\title{
Effect of hydrogen peroxide on $\mathrm{Na}^{+}, \mathrm{K}^{+}$-ATPase activity in spermatozoa of infertile men
}

\author{
R. V. Fafula, O. I. Meskalo, E. I. Lychkovskyy, U. P. Iefremova, O. K. Onofrovych, \\ H. V. Maksymyuk, O. V. Melnyk, I. A. Nakonechnyi, D. Z. Vorobets, Z. D. Vorobets
}

Danylo Halytsky Lviv National Medical University, Lviv, Ukraine

Article info

Received 27.09.2017

Received in revised form 30.10.2017

Accepted 02.11.2017

Danylo Halytsky Lviv National Medical University,

Pekarska st., 69,

Lviv, 79010, Ukraine.

Tel. +38-097-29-680-69

E-mail:roman_fafula@ukr.net
Fafula, R. V., Meskalo, O. I., Lychkovskyy, E. I., Iefremova, U. P., Onufrovych, O. K., Maksymyuk, H. V., Melnyk, O. V., Nakonechnyi, I. A., Vorobets, D. Z., \& Vorobets, Z. D. (2017). Effect of hydrogen peroxide on $\mathrm{Na}^{+}, \mathrm{K}^{+}-\mathrm{ATP}_{\mathrm{T}}$. activity in spermatozoa of infertile men. Regulatory Mechanisms in Biosystems, 8(4), 521-526. doi:10.15421/021780

$\mathrm{Na}^{+}, \mathrm{K}^{+}$-ATPase plays an essential role in sperm motility, hyperactivation, chemotaxis, acrosome reaction etc. $\mathrm{Na}^{+}, \mathrm{K}^{+}$-ATPase is sensitive to ROS insult. Apart from production of highly reactive molecules, $\mathrm{H}_{2} \mathrm{O}_{2}$ can exert a number of direct effects on cells, their metabolism and enzymes. In the present study, exposure to exogenous $\mathrm{H}_{2} \mathrm{O}_{2}$ was used to characterize the effects of $\mathrm{H}_{2} \mathrm{O}_{2}$ on $\mathrm{Na}^{+}, \mathrm{K}^{+}$-ATPase activity in spermatozoa of infertile men with different forms of pathospermia. It was shown that $\mathrm{Na}^{+}, \mathrm{K}^{+}$-ATPase activities in spermatozoa of infertile men with different forms of pathospermia were inhibited by exposure to $\mathrm{H}_{2} \mathrm{O}_{2}(50-500 \mu \mathrm{M}) . \mathrm{H}_{2} \mathrm{O}_{2}$, one of the most toxic oxygen species, has the ability to depress $\mathrm{Na}^{+}, \mathrm{K}^{+}$-ATPase activity in a dose-dependent manner. Severe inhibition of the hydrolytic activity was observed when higher $\mathrm{H}_{2} \mathrm{O}_{2}$ were used. The time course of incubation with $100 \mu \mathrm{M} \mathrm{H}_{2} \mathrm{O}_{2}$ showed a sharp decrease in the enzyme activity during the first 5 min of incubation for both normozoospermic and pathozoospermic men. The enzymatic activity of $\mathrm{Na}^{+}, \mathrm{K}^{+}$-ATPase in the sperm was completely destroyed at 20 min for asthenozoospermic men and $30 \mathrm{~min}$ for normozoospermic men. We show that an administation of $\mathrm{H}_{2} \mathrm{O}_{2}$ inhibited $\mathrm{Na}^{+}, \mathrm{K}^{+}$-ATPase activity in normozoospermic samples with $\mathrm{IC}_{50}$ of $106.6 \pm 7.9 \mu \mathrm{M}$. $\mathrm{IC}_{50}$ for patients with asthenozoospermia was two times less than for healthy men with preserved fertility. For other studied groups, the differences in $\mathrm{IC}_{50}$ were not significant. These observations suggest that $\mathrm{Na}^{+}, \mathrm{K}^{+}$-ATPase in pathozoospermic samples is more vulnerable to $\mathrm{H}_{2} \mathrm{O}_{2}$-induced damage than in normozoospermic men. The Hill coefficient was significantly increased only for patients with asthenozoospermia, indicating increased positively cooperative binding. The decreases in $\mathrm{Na}^{+}, \mathrm{K}^{+}$-ATPase hydrolase activity in $\mathrm{H}_{2} \mathrm{O}_{2}$-treated sperm cells in men with normozoospermia were largely attenuated by exogenous GSH at $5 \mathrm{mM}$. This suggests that GSH partially protects the $\mathrm{Na}^{+}, \mathrm{K}^{+}$-ATPase from inhibition under experimental oxidative stress. However, treatment of oligo-, astheno- and oligoasthenozoospermic samples with $100 \mu \mathrm{M} \mathrm{H}_{2} \mathrm{O}_{2}$ and 5 mM GSH did not result in protection of $\mathrm{Na}^{+}, \mathrm{K}^{+}$-ATPase against induced oxidation, suggesting that the impaired $\mathrm{Na}^{+}, \mathrm{K}^{+}$-ATPase in pathozoospermic samples appears to be an irreversible event. In contrast, presence of GSH only after $\mathrm{H}_{2} \mathrm{O}_{2}$ treatment does not reverse $\mathrm{Na}^{+}, \mathrm{K}^{+}$-ATPase inhibition. This study has provided a deeper insight into the role $\mathrm{Na}^{+}, \mathrm{K}^{+}$-ATPase plays in sperm cells,it also could offer clues to the clinical application of antioxidant therapy in male infertility therapy.

Keywords: reactive oxygen species; enzyme inhibition; pathospermia; male infertility

\section{Introduction}

$\mathrm{Na}^{+}, \mathrm{K}^{+}$-ATPase $\left(\mathrm{Na}^{+}, \mathrm{K}^{+}\right.$-activated $\mathrm{Mg}^{2+}$-dependent ATP-hydrolase, EC 3.6.1.37) has been widely studied and verified in different cells, including spermatozoa (Thundathil et al., 2006). Two isoforms of the catalytic subunit of the $\mathrm{Na}^{+}, \mathrm{K}^{+}$-ATPase, $\alpha 1$ and $\alpha_{4}$ which have different biochemical properties, coexist in sperm cells. Spermatozoa from knockout mice lacking $\alpha_{4}$ were incapable of fertilizing eggs in vitro , indicating the essential role of $\mathrm{Na}^{+}, \mathrm{K}^{+}$ATPase for sperm fertility (Sanchez et al., 2006).

Hyperproduction of reactive oxygen species (ROS) can damage sperm cells and is considered to be one of the mechanisms of infertility (Mahfouz et al., 2010). Spermatozoa have an unusual lipid composition of plasma membranes which is distinct from those of mammalian somatic cells. They are rich in polyunsaturated fatty acids and are very susceptible to attack by ROS (Shi et al., 2010). ROS are continuously produced in most cells and their levels are regulated by a number of enzymatic and non-enzymatic antioxidants. They have drawn attention for their potential to disrupt normal cell functions by targeting proteins for modification. ROS include hydrogen peroxide, singlet oxygen, the superoxide radical and the hydroxyl radical. Hydrogen peroxide $\left(\mathrm{H}_{2} \mathrm{O}_{2}\right)$ is generated by the dismutation of the superoxide anion radical and can cross cell membranes more easily (Groeger et al., 2009). ROS can modify different biomolecules including the polyunsaturated fatty acids of sperm membranes, resulting in a lipid peroxidation and disruption of membrane proteins.

It is known that $\mathrm{Na}^{+}, \mathrm{K}^{+}$-ATPase plays a crucial role in cell signalling. $\mathrm{Na}^{+}, \mathrm{K}^{+}$-ATPase regulates cell motility, cell proliferation, glycogen synthesis, intracellular calcium and sodium homeostasis, calcium signalling, apoptosis etc. (Barwe et al., 2005; Khundmiri et al., 2006; Nguyen et al., 2007). The signaling functions of the enzyme were demonstrated in various cells including spermatozoa (Thundathil et al., 2006). Oxidative stress can activate the $\mathrm{Na}^{+}, \mathrm{K}^{+}$ATPase signalling. $\mathrm{H}_{2} \mathrm{O}_{2}$ and exogenously added glucose oxidase (which generates a sustained low level of $\mathrm{H}_{2} \mathrm{O}_{2}$ ) activates $\mathrm{Na}^{+}, \mathrm{K}^{+}$- 
ATPase signaling in cardiac myocytes (Liu et al., 2006). $\mathrm{Na}^{+}, \mathrm{K}^{+}$ATPase is sensitive to ROS insult. It is known that increases in superoxide anion/hydrogen peroxide and reactive nitrogen species nitric oxide, which are mainly produced by mitochondria, NADPH oxidase, xanthine oxidase and uncoupled NO synthesis, can modify the $\mathrm{Na}^{+}, \mathrm{K}^{+}$-ATPase $\alpha$ and $\beta$ subunit to inhibit the $\mathrm{Na}^{+}, \mathrm{K}^{+}$-ATPase enzymatic (ion exchange) activity (Petrushanko et al., 2012; Liu et al., 2012). Exogenous addition of $\mathrm{H}_{2} \mathrm{O}_{2}$ has been shown to increase intracellular ROS levels in spermatozoa (Mahfouz et al., 2008). Apart from production of highly reactive molecules, $\mathrm{H}_{2} \mathrm{O}_{2}$ can exert a number of direct effects on cells, their metabolism and enzymes. In the present study, exposure to exogenous $\mathrm{H}_{2} \mathrm{O}_{2}$ was used to characterize the effects of $\mathrm{H}_{2} \mathrm{O}_{2}$ on $\mathrm{Na}^{+}, \mathrm{K}^{+}$-ATPase activity in spermatozoa of infertile men with different forms of pathospermia.

\section{Materials and methods}

Patients. 24 infertile men with different forms of pathospermia were involved in this study. They were recruited between September 2016 and February 2017. A detailed medical history was performed in all studied cases. Exclusion criteria: subjects currently on any medication or antioxidant supplementation were not included. In addition, subjects with infertility lasting over 10 years, azoospermia, genital infection, chronic illness and serious systemic diseases, smokers and alcoholic men were excluded from the study because of their well-known high seminal reactive oxygen species levels and decreased antioxidant activity, which may affect ATPase activities.

The control group consisted of 13 healthy men with somatic fertility, normozoospermia and confirmed parenthood (married for $3-10$ years and have healthy $1-3$ children). Semen samples were obtained by masturbation and collected into sterile containers, following 3-5 days' abstinence from sexual activity. After liquefaction at $37{ }^{\circ} \mathrm{C}$ with $5 \% \mathrm{CO}_{2}$ in air, semen samples were examined for volume, sperm concentration, $\mathrm{pH}$, morphology and motility according to World Health Organization guidelines (WHO, 2010). Before participating in the study, all the men were made aware of patient information leaflets and gave informed consent to participate in the research. Terms of sample selection meet the requirements of the principles of Helsinki Declaration on Protection of Human Rights, Convention of Europe Council on Human Rights and Biomedicine and the provisions of laws of Ukraine. Approval for study was taken from the Ethics Committee of Danylo Halytsky Lviv National Medical University. All patients and healthy donors gave written informed consent to participate in the research (Ethical Committee Approval, protocol No 2 from February 16, 2015).

Cell preparation. Sperm cells were washed from semen plasma by three times centrifugation at 3,000 $\mathrm{g}$ for $10 \mathrm{~min}$ in media which contained (mM): $120 \mathrm{NaCl}, 30 \mathrm{KCl}, 30$ Hepes (pH 7.4). The content of total protein in the samples was determined by the Lowry method using a kit to determine its concentration ("Simko Ltd"). The aliquots were subjected to exogenous ROS stimulation with $\mathrm{H}_{2} \mathrm{O}_{2}\left(5 \mathrm{~min}, 37^{\circ} \mathrm{C}, 5 \% \mathrm{CO}_{2}\right.$ ) at different concentrations (50, 100 and $500 \mu \mathrm{M}$ ) (if nothing else is indicated). Sperm samples without exogenous $\mathrm{H}_{2} \mathrm{O}_{2}$ served as control in the study. Also, when indicated, reduced glutathione (5.0 mM GSH) was present during the $\mathrm{H}_{2} \mathrm{O}_{2}-$ treatment or was introduced for 10 min only after $\mathrm{H}_{2} \mathrm{O}_{2}$-treatment.

Assay of $\mathrm{Na}^{+}, \mathrm{K}^{+}$-ATPase activity. Determination of $\mathrm{Na}^{+}, \mathrm{K}^{+}$ATPase activities was carried out in permeabilized spermatozoa. The detergent saponin in a final concentration of $0.5 \%$ was added to sperm suspension for permeabilization of sperm membranes. The total $\mathrm{Na}^{+}, \mathrm{K}^{+}$-ATPase activity was assayed with the following incubation medium (mM): $120 \mathrm{NaCl}, 30 \mathrm{KCl}, 5 \mathrm{MgCl}_{2}, 3$ ATP, 1 EGTA, 0.01 thapsigargin (specific inhibitor of SERCA), $1 \mathrm{NaN}_{3}$ (specific inhibitor of mitochondrial ATPase), 20 Hepes-Tris (pH 7.4; at $37^{\circ} \mathrm{C}$ ). The protein concentration did not exceed $50 \mathrm{mg} / \mathrm{ml}$. The reaction was started by addition of aliquot of permeabilized sperm cells. After a 5 min incubation, $1 \mathrm{ml}$ of a stop solution containing (mM) $1.5 \mathrm{M}$ sodium acetate, $3.7 \%$ formaldehyde, $14 \%$ ethanol, $5 \%$ trichloroacetic acid
(pH 4.3) acid was added. $\mathrm{P}_{\mathrm{i}}$ was determined by the Fiske-Subbarow method using assay kit "Simko Ltd" (Ukraine). Ouabain-sensitive $\mathrm{Na}^{+}, \mathrm{K}^{+}$-ATPase activity was determined as the difference in ATP hydrolysis in the absence and presence of $1 \mathrm{mM}$ ouabain, which is known to completely block the $\mathrm{Na}^{+}, \mathrm{K}^{+}$-ATPase.

Statistical analysis. Experimental data were processed by methods of variation statistics using software MS Office. The results are presented as the mean \pm standard error $(x \pm S E)$. Analysis of variance (ANOVA) was used to compare the difference in the means between infertile and healthy men. Differences were considered statistically significant at $\mathrm{P}<0.05$ for all analyses.

\section{Results}

$\mathrm{Na}^{+}, \mathrm{K}^{+}$-ATPase is one of the targets for ROS and is directly involved in oxidative stress. Spermatozoa were subjected to oxidative stress in the form of $\mathrm{H}_{2} \mathrm{O}_{2}$. It was shown that exposure of sperm cells to various concentrations of $\mathrm{H}_{2} \mathrm{O}_{2}$ demonstrated the ability of ROS to depress $\mathrm{Na}^{+}, \mathrm{K}^{+}$-ATPase activity in a dose-dependent manner. The low concentrations of $\mathrm{H}_{2} \mathrm{O}_{2}$ noticeably decreased the $\mathrm{Na}^{+}, \mathrm{K}^{+}$-ATPase activity, but they did not lower $\mathrm{Na}^{+}, \mathrm{K}^{+}$-ATPase activity dramatically, contrary to the higher concentrations. Specifically, $\mathrm{Na}^{+}, \mathrm{K}^{+}$-ATPase activity of sperm cells decreased to $94.0 \pm 7.4$ and $37.6 \pm 5.9 \%$ of initial activity in spermatozoa of healthy men (normozoospermia) treated with $50 \mu \mathrm{M}$ and $100 \mu \mathrm{M} \mathrm{H}_{2} \mathrm{O}_{2}$, respectively (Fig. 1). However, the residual enzyme activities (10.6 $\pm 1.9 \%$ of initial activity) remain.

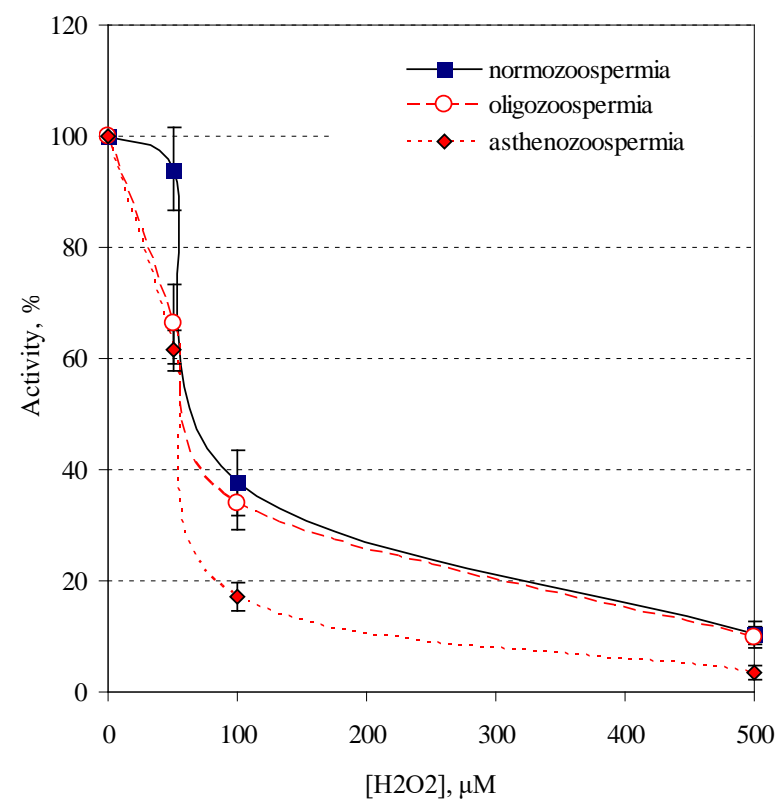

Fig. 1. Effect of hydrogen peroxide on the ouabain-sensitive $\mathrm{Na}^{+}, \mathrm{K}^{+}$-ATPase activity of spermatozoa of fertile and infertile men; data are presented as $x \pm S E, n=4-6$

When sperm cells of patients with pathospermia were exposed to various concentrations of $\mathrm{H}_{2} \mathrm{O}_{2}$, a dose-dependent inhibition of $\mathrm{Na}^{+}, \mathrm{K}^{+}$-ATPase enzymatic activity was also seen. For example, in patients with oligozoo- and asthenozoospermia the $\mathrm{Na}^{+}, \mathrm{K}^{+}$-ATPase activity of sperm cells decreased to $33.9 \pm 4.6$ and $17.3 \pm 5.8 \%$ of initial activity when treated with $100 \mu \mathrm{M} \mathrm{H}_{2} \mathrm{O}_{2}$, respectively. Similar results were obtained for sperm cells of patients with oligoasthenozoospermia (data not shown). Also, sperm cells were incubated with $100 \mu \mathrm{M} \mathrm{H}_{2} \mathrm{O}_{2}$ at different times and then $\mathrm{Na}^{+}, \mathrm{K}^{+}$-ATPase activity was determined (Fig. 2). The time course of incubation with $100 \mu \mathrm{M} \mathrm{H}_{2} \mathrm{O}_{2}$ showed a sharp decrease in the enzyme activity during the first 5 min of incubation for both normozoospermic and pathozoospermic men. The enzymatic activity of the sperm $\mathrm{Na}^{+}, \mathrm{K}^{+}$-ATPase was completely destroyed at $20 \mathrm{~min}$ for asthenozoospermic men and $30 \mathrm{~min}$ for normozoospermic men. 


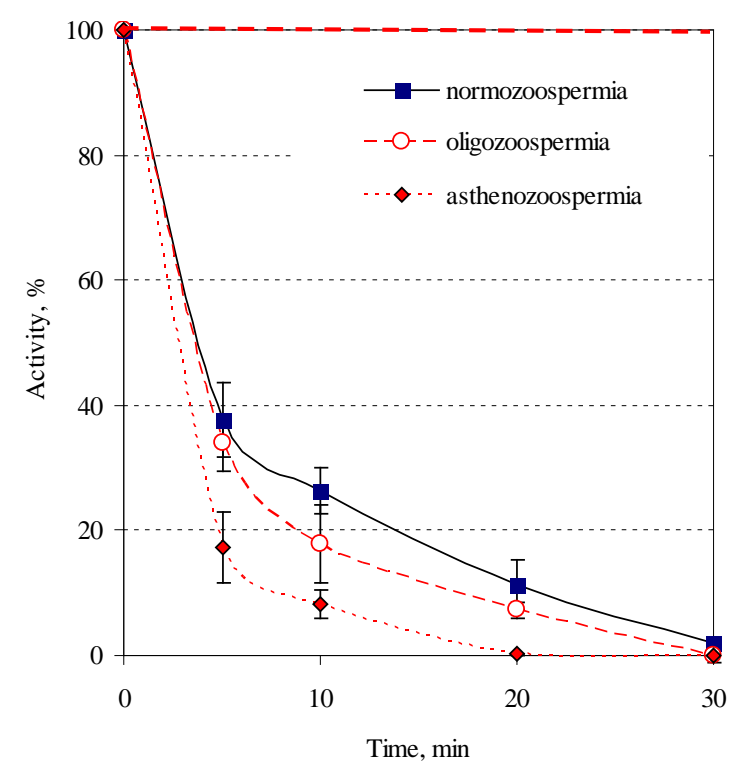

Fig. 2. Time course of $\mathrm{Na}^{+}, \mathrm{K}^{+}$-ATPase inhibition by $\mathrm{H}_{2} \mathrm{O}_{2}$; data are presented as $x \pm S E, n=4-6$

In order to elucidate the possible mechanism of $\mathrm{H}_{2} \mathrm{O}_{2}$ inhibitory effect the main kinetic parameters of inhibition were determined. Linearization of concentration curves in Hill's plot is represented on Figure 3. Obtained values of half maximal inhibitory concentration $\left(\mathrm{IC}_{50}\right)$ and Hill coefficient $(\mathrm{nH})$ are represented in Table 1 . The susceptibility of $\mathrm{Na}^{+}, \mathrm{K}^{+}$-ATPase to $\mathrm{H}_{2} \mathrm{O}_{2}$ in healthy men differed greatly from that of pathozoospermic patients. This is evidenced by the fact that $\mathrm{IC}_{50}$ for inhibition of $\mathrm{Na}^{+}, \mathrm{K}^{+}$-ATPase by $\mathrm{H}_{2} \mathrm{O}_{2}$ was greater for normozoospermic than for patients with oligo-, asthenoand oligoasthenozoospermia. $\mathrm{IC}_{50}$ for patients with asthenozoospermia was two times less than for healthy men with preserved fertility $(\mathrm{P}<0.05)$. For other studied groups the differences in $\mathrm{IC}_{50}$ were not significant. These observations suggest that $\mathrm{Na}^{+}, \mathrm{K}^{+}$-ATPase in pathozoospermic samples is more vulnerable to $\mathrm{H}_{2} \mathrm{O}_{2}$ induced damage than in normozoospermic men. The Hill coefficient was significantly increased only for patients with asthenozoospermia indicating increased positively cooperative binding.

\section{Table 1}

Inhibition parameters of $\mathrm{Na}^{+}, \mathrm{K}^{+}$-ATPase of the ouabain-sensitive $\mathrm{Na}^{+}, \mathrm{K}^{+}$-ATPase of spermatozoa of fertile and infertile men by $\mathrm{H}_{2} \mathrm{O}_{2}$

\begin{tabular}{lcccc}
\hline \multirow{2}{*}{$\begin{array}{c}\text { Kinetic } \\
\text { parameters }\end{array}$} & \multirow{2}{*}{$\begin{array}{c}\text { Normozoo- } \\
\text { spermic men }\end{array}$} & $\begin{array}{c}\text { oligozoo- } \\
\text { spermia }\end{array}$ & $\begin{array}{c}\text { asthenozoo- } \\
\text { spermia }\end{array}$ & $\begin{array}{c}\text { oligoastheno- } \\
\text { zoospermia }\end{array}$ \\
\hline $\mathrm{IC}_{50}, \mu \mathrm{M}$ & $106.6 \pm 21.9$ & $74.6 \pm 9.8$ & $52.8 \pm 3.2^{*}$ & $83.9 \pm 8.0$ \\
$n_{\mathrm{H}}$ & $1.42 \pm 0.18$ & $1.45 \pm 0.16$ & $2.00 \pm 0.15^{*}$ & $1.52 \pm 0.11$ \\
\hline
\end{tabular}

Note: data are presented as means \pm standard error; $\mathrm{n}=4-6$; * $-\mathrm{P}<0.05$ compared to normozoospermic men (men with preserved fertility).

It is known that catalytic activity of the $\mathrm{Na}^{+}, \mathrm{K}^{+}$-ATPase protein is critically dependent on free SH groups. Therefore, we next tested whether glutathione (GSH) protected $\mathrm{H}_{2} \mathrm{O}_{2}$-induced inhibition of the enzyme. A single concentration of $100 \mu \mathrm{M} \mathrm{H}_{2} \mathrm{O}_{2}$ was chosen, as this was close to the $\mathrm{IC}_{50}$ value for $\mathrm{Na}^{+}, \mathrm{K}^{+}$-ATPase inhibition (Table 1). In the present study, the decreases in $\mathrm{Na}^{+}, \mathrm{K}^{+}$-ATPase hydrolase activity in $\mathrm{H}_{2} \mathrm{O}_{2}$-treated sperm cells in men with normozoospermia were largely attenuated by exogenous GSH at $5 \mathrm{mM}$ (Fig. 4a).

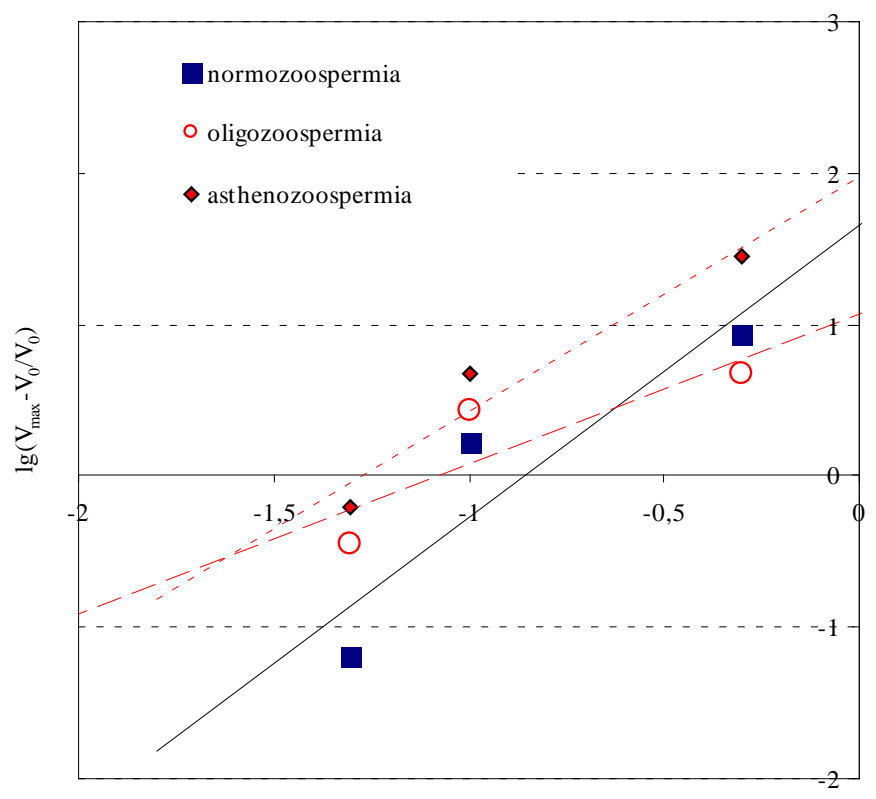

$\lg \left[\mathrm{H}_{2} \mathrm{O}_{2}\right], \mathrm{MM}$

Fig. 3. Linearization of concentration curves represented on Fig. 1 in Hill's plot: $x \pm S E, n=4-6$; $R^{2}>0.85$

Specifically, the effect of $100 \mathrm{mM} \mathrm{H} \mathrm{H}_{2} \mathrm{O}_{2}$ in absence of GSH in incubation medium resulted in decrease of $\mathrm{Na}^{+}, \mathrm{K}^{+}$-ATPase activity to $37.6 \pm 5.9 \%$ of initial activity, while in presence of $5 \mathrm{mM}$ GSH no inhibitory effect was noted $\left(\mathrm{Na}^{+}, \mathrm{K}^{+}\right.$-ATPase activity was $85.6 \pm 8.8 \%$ of initial activity). This suggests that GSH partially protects the $\mathrm{Na}^{+}, \mathrm{K}^{+}$-ATPase from inhibition under experimental oxidative stress. However, treatment of oligozoospermic samples with $100 \mu \mathrm{M} \mathrm{H}_{2} \mathrm{O}_{2}$ and $5 \mathrm{mM}$ GSH did not result in a protection of $\mathrm{Na}^{+}, \mathrm{K}^{+}$-ATPase against induced oxidation, suggesting that the impaired $\mathrm{Na}^{+}, \mathrm{K}^{+}$ATPase in oligozoospermic samples appears to be an irreversible event (Fig. 4b). Similar results were obtained for asthenozoospermic and oligoasthenozoospermic samples (data not shown).
GSH alone significantly did not alter the $\mathrm{Na}^{+}, \mathrm{K}^{+}$-ATPase hydrolase activity in both normozoospermic and pathospermic samples (Fig. 5). Presence of GSH during $\mathrm{H}_{2} \mathrm{O}_{2}$ treatment had a protective effect on $\mathrm{Na}^{+}, \mathrm{K}^{+}$-ATPase activity and confers protection against oxidative stress. Thus it appears that GSH effectively "scavenges" $\mathrm{H}_{2} \mathrm{O}_{2}$ and, thus, prevents $\mathrm{Na}^{+}, \mathrm{K}^{+}$-ATPase inhibition.

In contrast, presence of GSH only after $\mathrm{H}_{2} \mathrm{O}_{2}$ treatment does not reverse $\mathrm{Na}^{+}, \mathrm{K}^{+}$-ATPase inhibition (data not shown). It is known that $\mathrm{H}_{2} \mathrm{O}_{2}$ can oxidize $\mathrm{SH}$ groups to disulfides, which leads to the enzyme disruption. However, addition of disulfide-reducing agents GSH after $\mathrm{H}_{2} \mathrm{O}_{2}$ exposure in our experiments did not result in a recovery of $\mathrm{Na}^{+}, \mathrm{K}^{+}$-ATPase activity. 

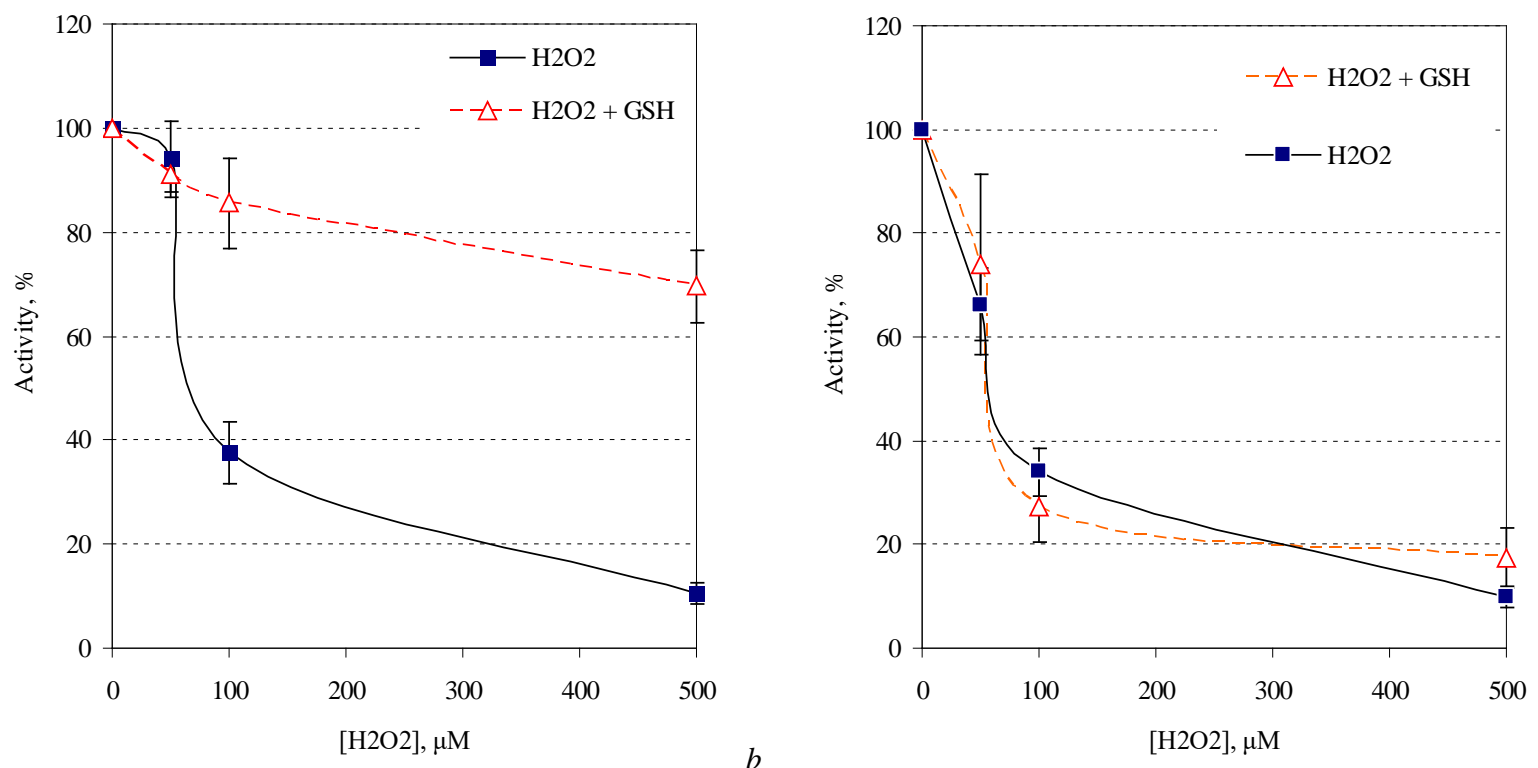

Fig. 4. Effects of $0.1 \mathrm{mM} \mathrm{H}_{2} \mathrm{O}_{2}$ and $5 \mathrm{mM} \mathrm{GSH}$ on the ouabain-sensitive $\mathrm{Na}^{+}, \mathrm{K}^{+}$-ATPase of spermatozoa of fertile men $(a)$ and infertile men (oligozoospermia) $(b): \mathrm{x} \pm \mathrm{SE}, \mathrm{n}=4-6$

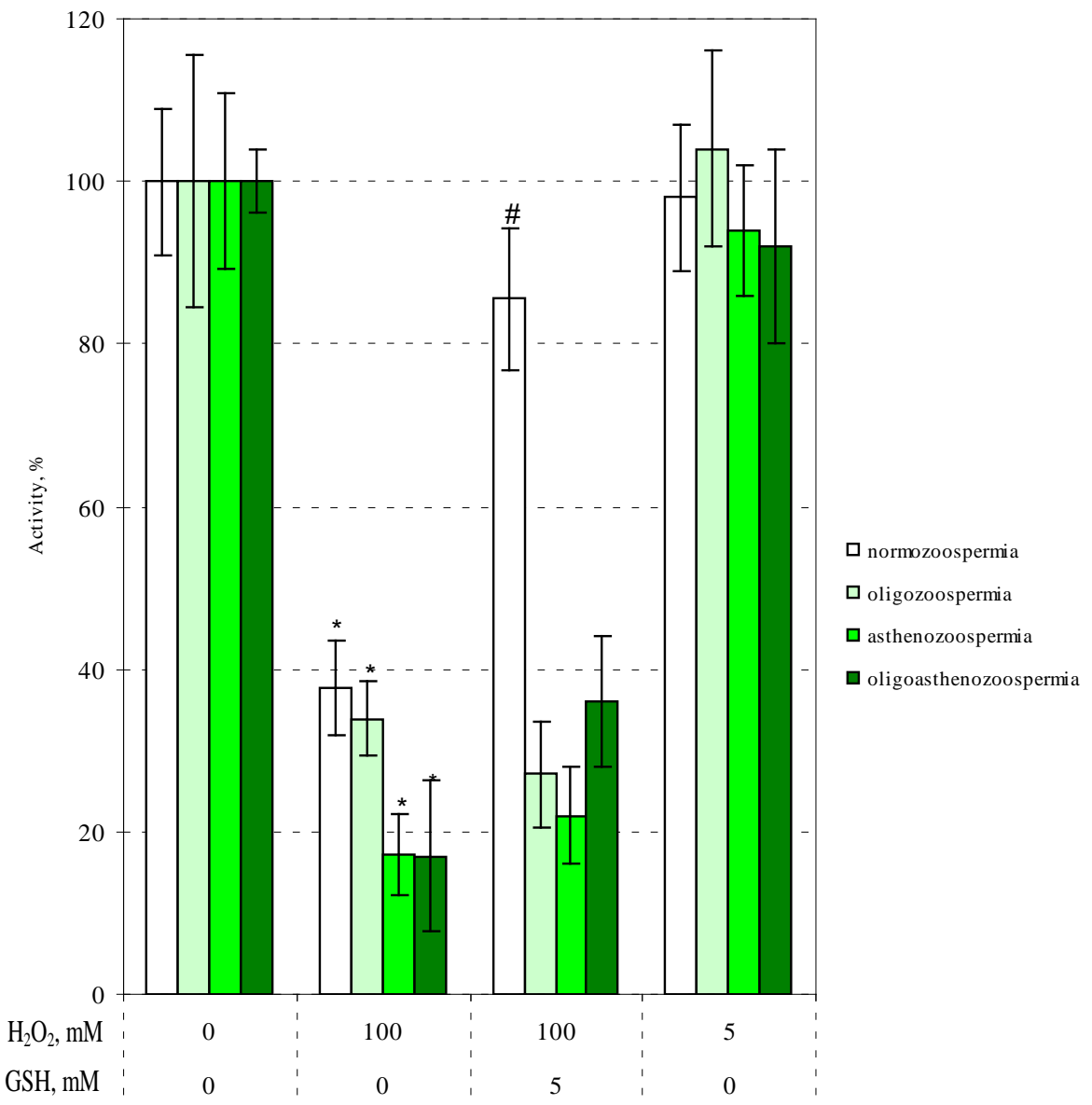

Fig. 5. Effects of $0.1 \mathrm{mM} \mathrm{H}_{2} \mathrm{O}_{2}$ and $5 \mathrm{mM} \mathrm{GSH}$ on the ouabain-sensitive $\mathrm{Na}^{+}, \mathrm{K}^{+}$-ATPase of spermatozoa of fertile and infertile men with different forms of pathospermia; $\mathrm{x} \pm \mathrm{SE}, \mathrm{n}=4-6$; * $-\mathrm{P}<0.05$ compared to normozoospermic men (men with preserved fertility); $\#-\mathrm{P}<0.05$ compared to data without exogenous GSH

\section{Discussion}

In our previous study (Meskalo et al., 2017), we found that spermatozoa of men with normozoospermia showed activity of ouabainsensitive $\mathrm{Na}^{+}, \mathrm{K}^{+}$-ATPase about $46.3 \pm 4.2 \mathrm{nmol} \mathrm{Pi} / \mathrm{min} \bullet \mathrm{mg}$ protein. Oligozoo-, asthenozoo-, oligoasthenozoo- and leucocytospermic patients have significantly impaired $\mathrm{Na}^{+}, \mathrm{K}^{+}$-ATPase compared to healthy men. In present study, $\mathrm{H}_{2} \mathrm{O}_{2}$, one of the most toxic oxygen species, has the ability to depress $\mathrm{Na}^{+}, \mathrm{K}^{+}$-ATPase activity in a dosedependent manner.

Overall, our results are consistent with several other studies. In particular, $\mathrm{Na}^{+}, \mathrm{K}^{+}$-ATPase activity was markedly inhibited in ghost cells in the presence of $0.5 \mathrm{mM} \mathrm{H}_{2} \mathrm{O}_{2}$ (Derham et al., 2003). Liu et al. showed that ROS stress acted as ouabain and stimulated endocytosis of the $\mathrm{Na}^{+}, \mathrm{K}^{+}$-ATPase, which resulted in a significant inhibition of $\mathrm{Na}^{+}, \mathrm{K}^{+}$-ATPase activity (Liu et al., 2004). However, conflicting data 
have been obtained in other studies. In some earlier studies researchers have shown that $\mathrm{H}_{2} \mathrm{O}_{2}$ increases $\mathrm{Na}^{+}, \mathrm{K}^{+}$-pump activity in bovine pulmonary arterial endothelial cells (Meharg et al., 1993). A sharp increase in $\mathrm{Na}^{+}, \mathrm{K}^{+}$-ATPase activity was observed in Leishmania amazonensis in response to low increased amounts $(0.1 \mu \mathrm{M})$ of $\mathrm{H}_{2} \mathrm{O}_{2}$ (Rocco-Machado et al., 2015).

Oxidative stress mediated by lipid peroxidation of sperm membranes may be responsible for the inhibition of $\mathrm{Na}^{+}, \mathrm{K}^{+}$-ATPase. ROS attack polyunsaturated fatty acids of membrane phospholipids, can modify different biomolecules, resulting in a lipid peroxidation. Spermatozoa have an unusual lipid composition of plasma membranes which is distinct from those of mammalian somatic cells. They are rich in polyunsaturated fatty acids and are very susceptible to attack by ROS. Thiobarbituric acid reactive substances (TBARS) are the more important marker of lipid peroxidation, which has been used to monitor the degree of peroxidative damage in spermatozoa (Januszewski et al., 2005). In our previous study, the increased TBARS content has been noted in sperm cells of infertile men compared with men with preserved fertility (Fafula et al., 2017).

It is known that catalytic activity of the $\mathrm{Na}^{+}, \mathrm{K}^{+}$-ATPase protein is critically dependent on free $\mathrm{SH}$ groups. It was found that control spermatozoa (healthy men with normozoospermia) exhibited $\mathrm{Na}^{+}, \mathrm{K}^{+}$ATPase and free -SH content significantly higher than those of as thenozoospermic patients (Vignini et al., 2009). A decrease in the number of free -SH groups suggests that the SH groups may have been oxidized to disulfides by $\mathrm{H}_{2} \mathrm{O}_{2}$. However, in another study no correlation was found between $\mathrm{Na}^{+}, \mathrm{K}^{+}$-ATPase activity and $\mathrm{SH}$ content (Koçak-Toker et al., 2002). It is also known that different enzyme and non-enzyme antioxidants and some inhibitors of oxidase activity can attenuate ROS mediated inhibition of $\mathrm{Na}^{+}, \mathrm{K}^{+}$-ATPase activity. Intracellular GSH depletion is capable of sensitizing many types of cells to apoptosis (Tsai-Turton and Luderer, 2006), however, little is known concerning the relationship between intracellular GSH loss and $\mathrm{Na}^{+}, \mathrm{K}^{+}$-ATPase in sperm cells. Therefore, we tested whether GSH protected $\mathrm{H}_{2} \mathrm{O}_{2}$-induced inhibition of $\mathrm{Na}^{+}, \mathrm{K}^{+}$-ATPase. We found that a decrease in $\mathrm{Na}^{+}, \mathrm{K}^{+}$-ATPase hydrolase activity in $\mathrm{H}_{2} \mathrm{O}_{2}$-treated sperm cells in men with normozoospermia was largely attenuated by exogenous GSH at $5 \mathrm{mM}$. This suggests that GSH partially protects the $\mathrm{Na}^{+}, \mathrm{K}^{+}$-ATPase from inhibition under experimental oxidative stress. Similar results which show protective effects of $\mathrm{GSH}$ on $\mathrm{Na}^{+}, \mathrm{K}^{+}$ATPase against oxidation were demonstrated earlier (Schulpis et al., 2006). However, administration of $\mathrm{GSH}$ only after $\mathrm{H}_{2} \mathrm{O}_{2}$ treatment does not reverse $\mathrm{Na}^{+}, \mathrm{K}^{+}$-ATPase inhibition. This result may be explained by assumption that GSH led to recovery of cysteines but not enzyme activity or that inhibition is the result of modifying other aminoacids or not only -SH groups account for the $\mathrm{Na}^{+}, \mathrm{K}^{+}$-ATPase inhibition by $\mathrm{H}_{2} \mathrm{O}_{2}$.

$\mathrm{Na}^{+}, \mathrm{K}^{+}$-ATPase may serve as a molecular target for ROS and signaling via the $\mathrm{Na}^{+}, \mathrm{K}^{+}$-ATPase by ROS may generate second messengers such as intracellular $\mathrm{Ca}^{2+}$ ions. It was shown that ROS-induced changes in intracellular $\mathrm{Ca}^{2+}$ appeared to be correlated to its effect on the $\mathrm{Na}^{+}, \mathrm{K}^{+}$-ATPase. In addition, ouabain and ROS exhibited the additive effect on intracellular $\mathrm{Ca}^{2+}$, suggesting a common target for both stimuli (Liu et al., 2006). It was found that $\mathrm{Na}^{+}, \mathrm{K}^{+}$-ATPase is sensitive to redox and oxygen status of cell (Bogdanova et al., 2006). $\mathrm{Na}^{+}, \mathrm{K}^{+}$-ATPase is redox-sensitive with an "optimal redox potential range," where ROS levels out of this "optimal range” are capable of inhibiting $\mathrm{Na}^{+}, \mathrm{K}^{+}$-ATPase activity (Petrushanko et al., 2006). Inhibition in the effect of ROS on $\mathrm{Na}^{+}, \mathrm{K}^{+}$-ATPase can be explained by protein modification. In purified renal $\mathrm{Na}^{+}, \mathrm{K}^{+}$-ATPase, peroxynitrite (ONOO) causes tyrosine nitration and cysteine thiol group modification of the $\mathrm{Na}^{+}, \mathrm{K}^{+}$-ATPase (Reifenberger et al., 2008).

Inhibition of sperm $\mathrm{Na}^{+}, \mathrm{K}^{+}$-ATPase activity could be explained by a direct effect of the exogenous $\mathrm{H}_{2} \mathrm{O}_{2}$, but could also result from the generation of ROS and reactive nitrogen species (RNS) by damaged spermatozoa. It was shown that mitochondria as the major site for ROS production can contribute significantly to oxidative stress in defective spermatozoa (Koppers et al., 2008). We believe that indirect effect of $\mathrm{H}_{2} \mathrm{O}_{2}$ is associated with damage to sperm cells, in particular mitochondria disruption causing the mitochondria to leak high levels of free electrons. In turn, damaged mitochondria contribute to the increase in ROS and RNS levels. The results support our assumption that exogenous $\mathrm{H}_{2} \mathrm{O}_{2}$ should adversely affect sperm motility parameters and corresponds to the results of other studies. Excessive ROS levels have been linked to lipid peroxidation of the sperm plasma membrane, resulting in a loss of membrane fluidity, structure and function (Mahfouz et al., 2009a). Undoubtedly, this study has provided a deeper insight into the role $\mathrm{Na}^{+}, \mathrm{K}^{+}$-ATPase plays in sperm cells, also could offer clues to the clinical application of antioxidant therapy in male infertility therapy.

\section{Conclusions}

$\mathrm{H}_{2} \mathrm{O}_{2}$, one of the most toxic oxygen species, has the ability to depress $\mathrm{Na}^{+}, \mathrm{K}^{+}$-ATPase activity in a dose-dependent manner. $\mathrm{IC}_{50}$ value for patients with asthenozoospermia was two times less than for healthy men with preserved fertility. These observations suggest that $\mathrm{Na}^{+}, \mathrm{K}^{+}$-ATPase in pathozoospermic samples is more vulnerable to $\mathrm{H}_{2} \mathrm{O}_{2}$ induced damage than in normozoospermic men. The Hill coefficient was significantly increased only for patients with asthenozoospermia, indicating increased positively cooperative binding. The decreases in $\mathrm{Na}^{+}, \mathrm{K}^{+}$-ATPase hydrolase activity in $\mathrm{H}_{2} \mathrm{O}_{2}$-treated sperm cells in men with normozoospermia were largely attenuated by exogenous GSH at 5mM.

The publication contains the results of studies conducted under the President of Ukraine's grant for competitive projects (project No $\Phi 63 / 97-2016$ from 10.08.2016 "Molecular biological regulatory mechanisms of disturbance of fertilizing ability spermatozoa and the development of new immunobiochemical diagnostic methods of fertility in men" (scientific supervisor Doc. Sci. D. Vorobets) of the State Fund for Fundamental Research (The President's Order No 97/2016-pп dated: April 13, 2016).

\section{References}

Barwe, S. P., Anilkumar, G., Moon, S. Y., Zheng, Y., Whitelegge, J. P., Rajasekaran, S. A., \& Rajasekaran, A. K. (2005). Novel role for Na,K-ATPase in phosphatidylinositol 3-kinase signaling and suppression of cell motility. Molecular Biology of the Cell, 16(3), 1082-1094.

Bogdanova, A., Petrushanko, I., Boldyrev, A., \& Gassmann, M. (2006). Oxygenand redox-induced regulaton of the $\mathrm{Na} / \mathrm{K}$ ATPase. Current Enzyme Inhibition, 2(1), 37-59.

Derham, B. K., Ellory, J. C., Bron, A. J., \& Harding, J. J. (2003). The molecular chaperone a-crystallin incorporated into red cell ghosts protects membrane $\mathrm{Na} / \mathrm{K}-\mathrm{ATPase}$ against glycation and oxidative stress. European Journal of Biochemistry, 270, 2605-2611.

Fafula, R. V., Onofrovych, O. K., Iefremova, U. P., Nakonechnyi, I. A., \& Vorobets, Z. D. (2017). Intensity of processes of lipid peroxidation in sperm of men with fertility breach. Bulletin of Problems Biology and Medicine, 135, 199-204.

Groeger, G., Mackey, A. M., Pettigrew, C. A., Bhatt, L., \& Cotter, T. G. (2009). Stress-induced activation of Nox contributes to cell survival signalling via production of hydrogen peroxide. Journal of Neurochemistry, 109, 1544 1554.

Januszewski, A. S., Alderson, N. L., Jenkins, A. J., Thorpe, S. R., \& Baynes, J. W. (2005). Chemical modification of proteins during peroxidation of phospholipids. Journal of Lipid Research, 56, 1440-1449.

Khundmiri, S. J., Metzler, M. A., Ameen, M., Amin, V., Rane, M. J., \& Delamere, N. A. (2006). Ouabain induces cell proliferation through calcium-dependent phosphorylation of Akt (protein kinase B) in opossum kidney proximal tubule cells. American Journal of Physiology, Cell Physiology, 291(6), 1247-1257.

Koçak-Toker, N., Aktan, G., \& Aykaç-Toker, G. (2002). The role of Na,K-ATPase in human sperm motility. International Joumal of Andrology, 25(3), 180-185.

Koppers, A. J., De Iuliis, G. N., Finnie, J. M., McLaughli, E. A., \& Aitken, R. J. (2008). Significance of mitochondrial reactive oxygen species in the generation of oxidative stress in spermatozoa. The Journal of Clinical Endocrinology and Metabolism, 93(8), 3199-3207.

Liu, C.-C.,Garcia, A., Mahmmoud, Y. A., Hamilton, E. J., Galougahi, K. K., Fry, N. A. S., Figtree, G. A., Comelius, F., Clarke, R. J., \& Rasmussen, H. H. (2012). Susceptibility of $\beta_{1} \mathrm{Na}^{+}-\mathrm{K}^{+}$pump subunit to glutathionylation and oxidative inhibition depends on conformational state of pump. Journal of Biological Chemistry, 287, 12353-12364. 
Liu, J.., Kesiry, R., Periyasamy, S. M., Malhotra, D., Xie, Z., \& Shapiro, J. I. (2004). Ouabain induces endocytosis of plasmalemmal Na/K-ATPase in LLC-PK1 cells by a clathrin-dependent mechanism. Kidney International, 66, 227-241.

Liu, L., Li, J., Liu, J., Yuan, Z., Pierre, S. V., Qu, W., Zhao, X., \& Xie, Z. (2006). Involvement of $\mathrm{Na}^{+} / \mathrm{K}^{+}$-ATPase in hydrogen peroxide-induced hypertrophy in cardiac myocytes. Free Radical Biology and Medicine, 41(10), 1548-1556.

Mahfouz, R. Z., Aziz, N., Sharma, R., Bykova, M., Sabanegh, E., \& Agarwal, A. (2008). Assessment of intracelular human sperm reactive oxygen species after hydrogen peroxide exposure using four different probes. Fertility and Sterility, 90(Suppl 1), 320-321.

Mahfouz, R. Z., du Plessis, S. S., Aziz, N., Sharma, R., Sabanegh, E., \& Agarwal, A. (2010). Sperm viability, apoptosis, and intracellular reactive oxygen species levels in human spermatozoa before and after induction of oxidative stress. Fertility and Sterility, 93(3), 814-821.

McKenna, M. J., Medved, I., Goodman, C. A., Brown, M. J., Bjorksten, A. R., Murphy, K. T., Petersen, A. C., Sostaric, S., \& Gong, X. (2006). N-acetylcysteine attenuates the decline in muscle $\mathrm{Na}^{+}, \mathrm{K}^{+}$-pump activity and delays fatigue during prolonged exercise in humans. Journal of Physiology, 576(1), 279-288.

Meharg, J. V., McGowan-Jordan, J., Charles, A., Parmelee, J. T., Cutaia, M. V., \& Rounds, S. (1993). Hydrogen peroxide stimulates sodium-potassium pump activity in cultured pulmonary arterial endothelial cells. American Journal of Physiology, 265(6), 613-621.

Meskalo, O., Fafula, R. V., Lychkovskyj, E. I., \& Vorobets, Z. D. (2017). $\mathrm{Na}^{+} \mathrm{K}^{+}$ATPase and $\mathrm{Ca}^{2+}, \mathrm{Mg}^{2+}$-ATPase activity in spermatozoa of infertile men with different forms of pathospermia. Studia Biologica, 11(2), 5-12.

Nguyen, N. T., Wallace, D. P., \& Blanco, G. (2007). Ouabain binds with high affinity to the Na,K-ATPase in human polycystic kidney cells and induces extracellular signal-regulated kinase activation and cell proliferation. Journal of the American Society of Nephrology, 18(1), 46-57.

Petrushanko, I. Y., Yakushev, S., Mitkevich, V. A., Kamanina, Y. V., Ziganshin, R. H., Meng, X., Anashkina, A. A., Makhro, A., Lopina, O. D., Gassmann, M., Makarov, A. A., \& Bogdanova, A. (2012). S-glutathionylation of the Na,KATPase catalytic alpha subunit is a determinant of the enzyme redox sensitivity. Joumal of Biological Chemistry, 287, 32195-32205.
Petrushanko, N., Bogdanov, E., Bulygina B., Grenacher, T., Leinsoo, A., Boldyrev, M., Gassmann, M., \& Bogdanova, A. (2006). Na-K-ATPase in rat cerebellar granule cells is redox sensitive. American Journal of Physiology, Regulatory Integrative and Comparative Physiology, 290(4), 916-925.

Reifenberger, M. S., Arnett, K. L., Gatto, C., \& Milanick, M. A. (2008). The reactive nitrogen species peroxynitrite is a potent inhibitor of renal Na-K-ATPase activity. American Journal of Physiology, 295(4), 1191-1198.

Rocco-Machado, N., Cosentino-Gomes, D., \& Meyer-Fernandes, J. R. (2015). Modulation of $\mathrm{Na}^{+} / \mathrm{K}^{+}$ATPase activity by hydrogen peroxide generated through heme in L. amazonensis. PLoS One, 10(6), e0129604.

Sanchez, G., Nguyen, A. T., Timmerberg, B., Tash, J. S., \& Blanco, G. (2006). The $\mathrm{Na}, \mathrm{K}-\mathrm{ATPase}$ a 4 isoform from humans has distinct enzymatic properties and is important for sperm motility. Molecular Human Reproduction, 12, 565-576.

Schulpis, K. H., Papassotiriou, I., Parthimos, T., Tsakiris, T., \& Tsakiris, S. (2006) The effect of L-cysteine and glutathione on inhibition of $\mathrm{Na}^{+}, \mathrm{K}^{+}$-ATPase activity by aspartame metabolites in human erythrocyte membrane. European Journal of Clinical Nutrition, 60(5), 593-597.

Shi, L. G., Yang, R. J., Yue, W. B., Xun, W. J., Zhang, C. X., Ren, Y. S., Shi, L., \& Lei, F. L. (2010). Effect of elemental nano-selenium on semen quality, glutathione peroxidase activity, and testis ultrastructure in male Boer goats. Animal Reproduction Science, 118 (2-4), 248-254.

Thundathil, J. C., Anzar, M., \& Buhr, M. M. (2006). Na ${ }^{+} / \mathrm{K}^{+}$-ATPase as a signaling molecule during bovine sperm capacitation. Biology of Reproduction, 75, 308-317.

Tsai-Turton, M., \& Luderer, U. (2006). Opposing effects of glutathione depletion and follicle-stimulating hormone on reactive oxygen species and apoptosis in cultured preovulatory rat follicles. Endocrinology, 147, 1224-1236.

Vignini, A., Buldreghini, E., Nanetti, L., Amoroso, S., Boscaro, M., Ricciardo-Lamonica, G., Mazzanti, L., \& Balercia, G. (2009). Free thiols in human spermatozoa: are $\mathrm{Na}^{+} / \mathrm{K}^{+}$-ATPase, $\mathrm{Ca}^{2+}$-ATPase activities involved in sperm motility through peroxynitrite formation? Reproductive BioMedicine Online, 18(1), 132-140.

WHO Laboratory Manual for the examination and processing of human semen, 5th ed. (2010). WHO. 